\title{
The deformation of retaining piles and ground surface under various support systems during deep excavation
}

\author{
Yiqun Tang ${ }^{1,2^{*}}$, Wenqiang Zhao ${ }^{2}$ and Jie Zhou ${ }^{1,2}$
}

\begin{abstract}
Background: Since the high-rise buildings and deep underground structures dramatically increases in urban area, the decent design and construction of deep excavations is essential before these structures are actually built up. The building area is very susceptible to the changes of their geo-environment, and even minor insecurity of a deep excavation may lead to a catastrophic failure of structures and deformation of the ground. Therefore, the adverse influence of deep excavation on the surrounding environment should be monitored and controlled stringently.

Results: Based on the real case of deep excavation in Xuzhou, China, a FDM numerical model, which was accomplished by FLAC-3D, was developed to evaluate the deformation of retaining piles and ground surface under various excavation support systems. The original pile-anchor support system was simulated as well as the proposed quincunx double-row piles support system. For the original support system, the deformations were discussed by comparing the numerical results with monitoring data. For the proposed support system, orthogonal tests were designed to evaluate the influence of multiple factors on the effectiveness of excavation support. The optimum solution for the proposed support system was obtained through orthogonal tests.
\end{abstract}

Conclusion: Results show that the pile space is the primary factor for the excavation-induced deformations, which can be reflected by the lateral displacement of retaining piles and the settlement around the excavation, while the row space has insignificant influence on the deformations. The conclusions of this paper can contribute to the design of similar projects and avoid excessive deformation of the ground during excavation in the future.

Keywords: Support systems, Monitoring, Numerical simulation, Orthogonal test

\section{Background}

Since the demand for space dramatically increases in modern cities, numerous high-rise buildings and deep underground structures (like parking structure, underground mall, metro system, and basement) appears in urban area. Before these structures are actually built up, the decent design and construction of deep excavations is essential. Unfortunately, the building area, which requires deep excavations, is commonly the area full of buildings, roads, and municipal pipeline. They

\footnotetext{
* Correspondence: tangyiqun2@tongji.edu.cn

'Department of Geotechnical Engineering, College of Civil Engineering, Key Laboratory of Geotechnical, 1239 Siping Road, Shanghai 200092, People's Republic of China

${ }^{2}$ Department of Geotechnical Engineering, College of Civil Engineering, Tongji University, 1239 Siping Road, Shanghai 200092, People's Republic of China
}

are very susceptible to the changes of their geoenvironment. Therefore, the adverse influence of deep excavation on the surrounding environment should be monitored and controlled stringently.

Though the deep excavation is a temporary project, its importance should not be underestimated. Even minor insecurity of a deep excavation may lead to a catastrophic failure of structures and deformation of the ground. The study of the adverse effect induced by deep excavation is urgently required. Peck (1969) proposed a dimensionless curve method to estimate the ground settlement around the excavation. This method is widely accepted and applied in practices. Ou et al. (1993) selected ten excavation cases in Taipei with good-quality construction and field observation data to study the characteristics of ground surface settlement during excavation, and proposed an empirical formula 


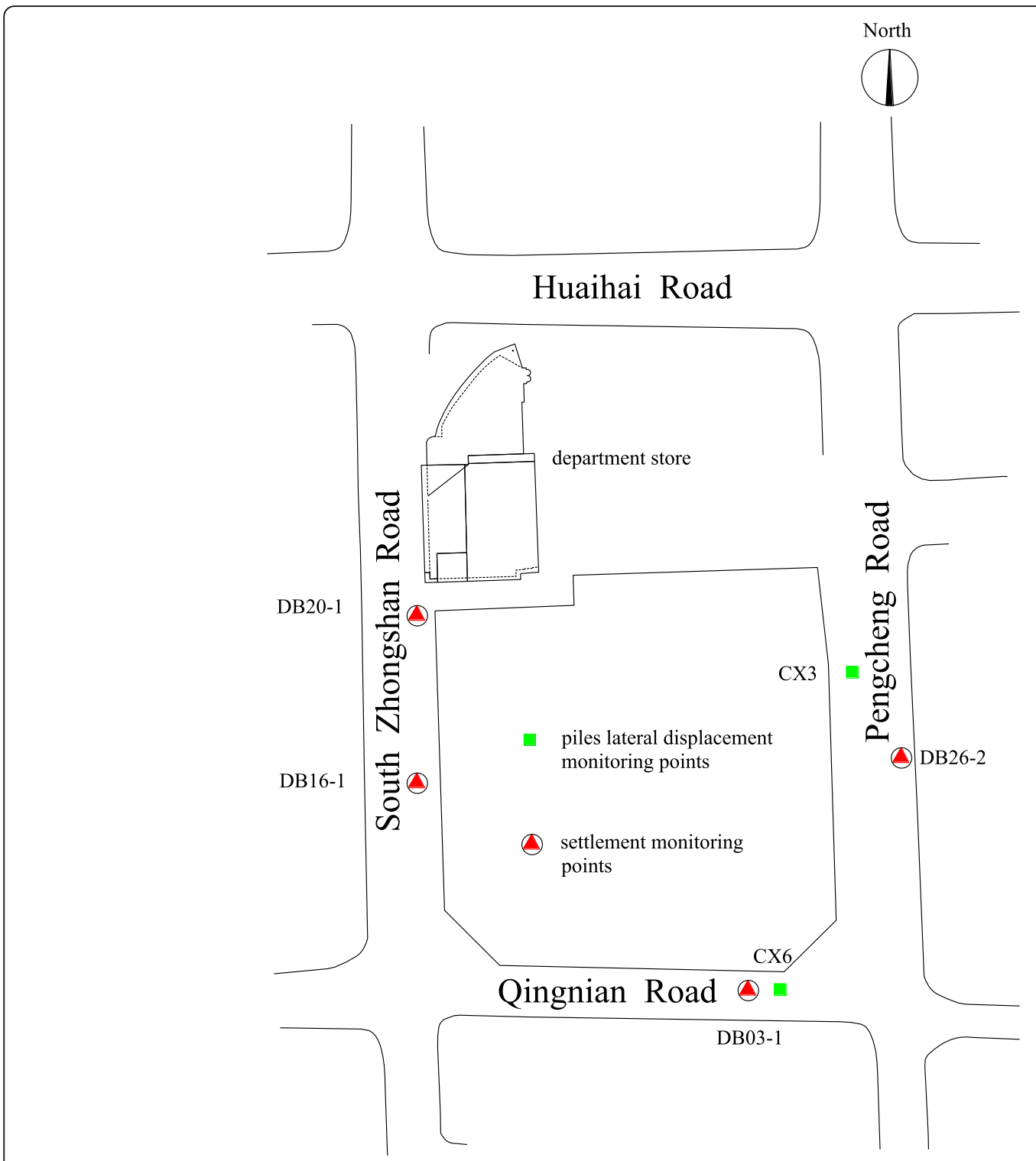

Fig. 1 Site Location and Layout of Monitoring Points. Through geotechnical investigation, the stratums of construction site are shown in Table 1

Table 1 Characteristic of the stratums in construction site

\begin{tabular}{llll}
\hline Stratum & Thickness $(\mathrm{m})$ & Average thickness $(\mathrm{m})$ & Characteristics description \\
\hline (1) Miscellaneous fill & $2.00 \sim 4.50$ & 2.97 & Variegated in color, and with loose structure. \\
(2) Silty clay & $0.70 \sim 3.40$ & 1.87 & Brownish yellow in color, and in soft-plastic state. \\
(3) Fill & $4.60 \sim 7.20$ & 5.73 & Grey in color, and in soft-plastic state. \\
(4) Clay & 1.65 & Yellow in color, and in hard-plastic state. \\
(5) Clay with lime concretion & $0.70 \sim 3.00$ & 2.74 & Brownish yellow in color, and in-hard plastic state. \\
(5-1 Clay & $1.90 \sim 3.20$ & 5.39 & Particle size of lime concretion is $0.50 \sim 5.00$ cm. \\
(6) Sandstone & $4.20 \sim 7.30$ & 6.16 & Brownish yellow in color, and in-hard plastic state. \\
(6- 1 Limestone & $4.60 \sim 7.20$ & Purple in color, and strongly weathered. \\
\hline
\end{tabular}




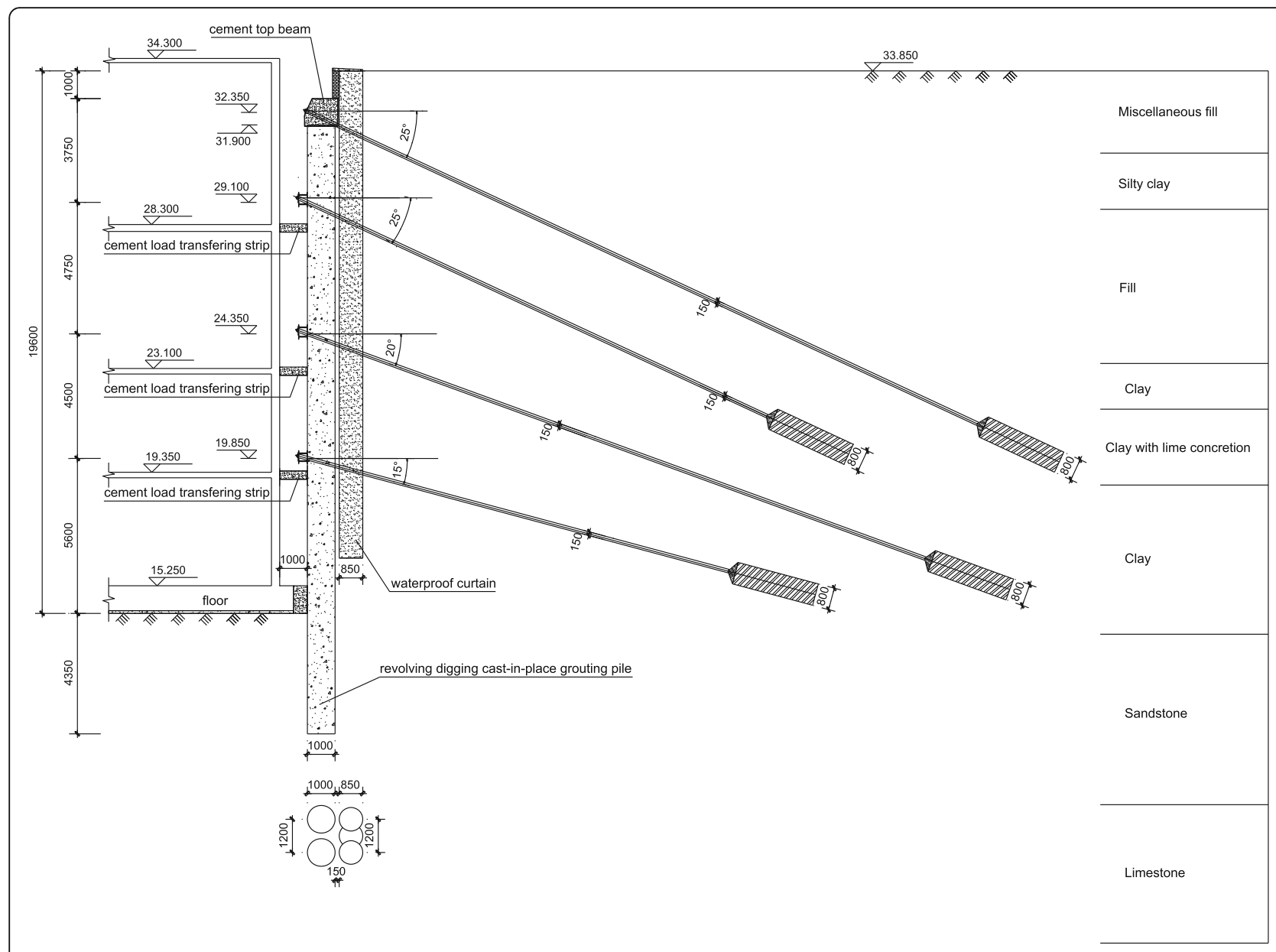

Fig. 2 Structural section of excavation support

to predict the ground surface settlement profile at the center section of an excavation. A clear understanding of the pile behavior during nearby excavations can be obtained from case studies with proper instrumentation. Finno et al. (1991) demonstrated that lateral soil movements from excavation activities could be detrimental to nearby existing piles by field observations, including lateral deformations of the sheet pile and lateral and vertical deformations of the main columns. Goh et al. (2003) carried out an actual full-scale instrumented study to examine the behavior of an existing pile due to nearby excavation activities resulting from the construction of a cut-and-cover tunnel. However, no comparisons could be made between the pile and wall behavior because of an inclinometer installed in the diaphragm wall was damaged.

Meanwhile, the modern computer technology is capable of processing staggering amount of data and simulating practical geotechnical engineering problems. Professional FEM and FDM simulation software products can consider the pile-soil interaction, group effect, complex boundary conditions and soil non-homogeneity (Zhang et al. 2011). Poulos and Chen (1997) established design charts for estimating pile bending moments and deflections based on results from a two-stage analysis procedure. The finiteelement method was used first to simulate the excavation

Table 2 Parameters of anchor cables

\begin{tabular}{lllllllll}
\hline Layer & $\begin{array}{l}\text { Horizontal } \\
\text { interval }(\mathrm{m})\end{array}$ & $\begin{array}{l}\text { Number of } \\
\text { steel strand }\end{array}$ & $\begin{array}{l}\text { Orifice relative } \\
\text { elevation }(\mathrm{m})\end{array}$ & $\begin{array}{l}\text { Drilling } \\
\text { angle }\left(^{\circ}\right)\end{array}$ & $\begin{array}{l}\text { Length of free } \\
\text { segment }(\mathrm{m})\end{array}$ & $\begin{array}{l}\text { Length of anchoring } \\
\text { section }(\mathrm{m})\end{array}$ & $\begin{array}{l}\text { Design value } \\
(\mathrm{kN})\end{array}$ & $\begin{array}{l}\text { Pre-stressing } \\
\text { value }(\mathrm{kN})\end{array}$ \\
\hline 1 & $1.20 / 2.40$ & 6 & -1.50 & 25 & 30 & 3 & 500 & 300 \\
2 & & -4.75 & 25 & 22 & & 750 & 450 \\
3 & & -9.50 & 20 & 27 & 850 & 510 \\
4 & & -14.00 & 15 & 19 & 800 & 480 \\
\hline
\end{tabular}


Table 3 Parameters of concrete bracings

\begin{tabular}{llll}
\hline Layer & $\begin{array}{l}\text { Relative } \\
\text { elevation }(\mathrm{m})\end{array}$ & \multicolumn{2}{c}{ Section size of bracing $(\mathrm{mm} \times \mathrm{mm})$} \\
\cline { 3 - 4 } & -1.75 & $1000 \times 900$ & $800 \times 900$ \\
\hline 1 & -6.45 & & $900 \times 900$ \\
2 & -11.65 & & \\
3 & -15.50 & & \\
4 & &
\end{tabular}

procedure and to generate free-field soil movements, that is, the soil movements that would occur without the presence of the pile. These generated lateral soil movements were then used as input into a boundary-element program to analyze pile response. Gao et al. (2010) developed a 3D model in FLAC-3D, which simulated the whole construction process of a deep excavation adjacent to a metro tunnel in Shanghai. The simulated results showed the reinforced foundations and underground structures around the deep excavation could effectively decrease nearby displacements. Zhou et al. (2011) developed a three dimensional numerical model through finite difference method based on a real dewatering case during the construction of Xujiahui metro station in Shanghai. The model was applied to calculate the dewatering-induced settlement around the deep excavation. The results were proven effective according to the monitoring data afterward. In the papers mentioned above, the numerical models were all applied to evaluate one specific support system for each case. However, the comparison of various support systems for the same case can also be realized through the numerical models.

In this paper, numerical models were developed in FLAC-3D to simulate the construction of a deep excavation in Xuzhou. Models of different cases (different support systems) were applied to calculate the deformations of piles and soils around the deep excavation, and the results of these cases were compared. Accordingly, this paper provided some guidelines for the similar projects.

\section{Study area}

The construction site is located in the downtown of Xuzhou, China. In geomorphology, the whole area belongs to the alluvial plain created by Yellow River. The original structures in this site were predominantly multi-story buildings, and those within the area of excavation have been demolished for the new project. Its specific site is shown in Fig. 1. In this case, the excavation area was about $26,000 \mathrm{~m}^{2}$ and its circumference was around $634 \mathrm{~m}$. The proposed high-rise doubletower building, which is a reinforced concrete tube frame structure, is $259 \mathrm{~m}$ high. The west tower, which is planned as residual area, has 67 stories above the ground and three-level basement. The east tower, which is planned as multi-functional area, has 60 stories and four-level basement. Also, there is a 9-story annex which is a frame-shear wall structure is planned for shopping

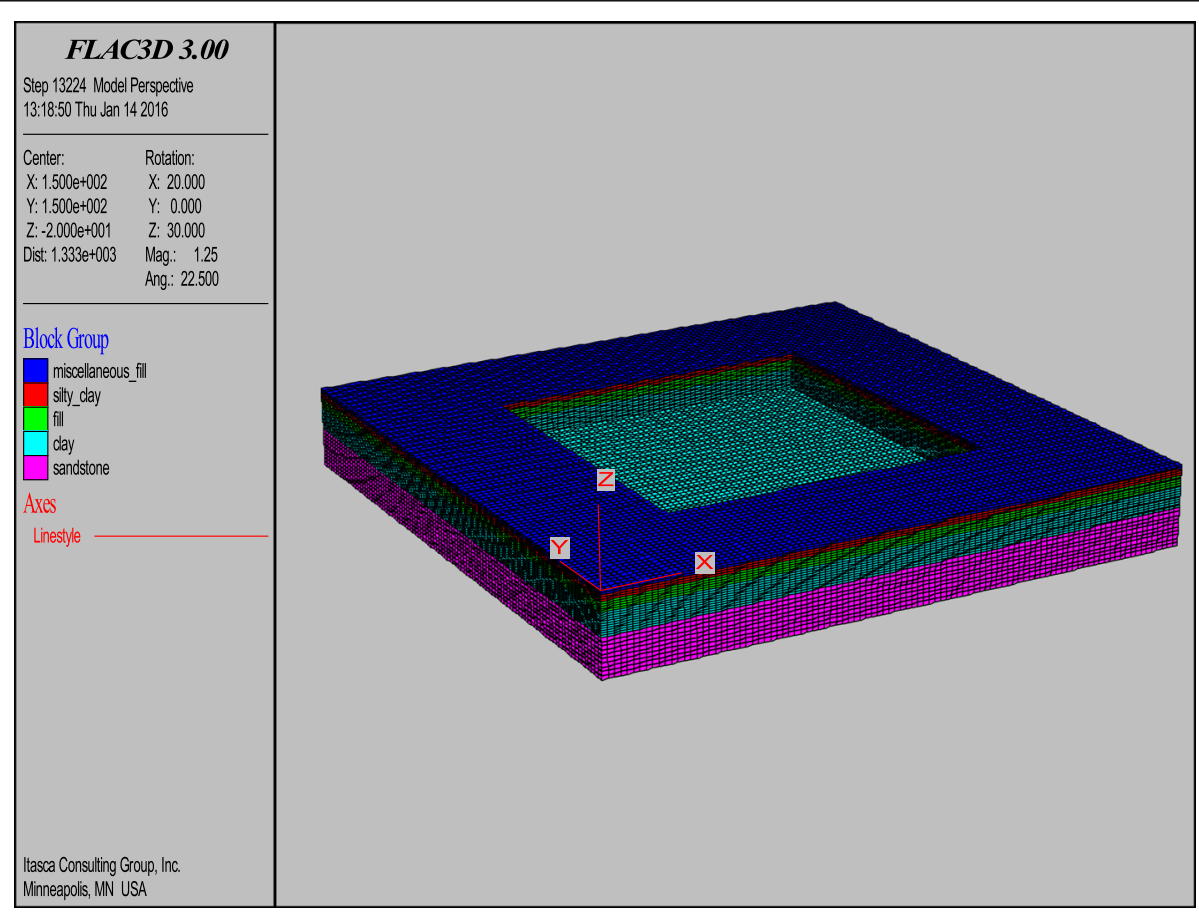

Fig. 3 Numerical model 
Table 4 Soil Parameters applied in numerical model

\begin{tabular}{|c|c|c|c|c|c|c|c|}
\hline Layer & Soil group & Thickness (m) & Weight density $\left(\mathrm{kN} / \mathrm{m}^{3}\right)$ & Cohesion (kPa) & Friction angle $\left(^{\circ}\right)$ & Shear modulus (MPa) & Bulk modulus (MPa) \\
\hline 1 & Miscellaneous fill & 2.30 & 17.50 & 7.00 & 10.00 & 4.48 & 12.50 \\
\hline 2 & Silty clay & 2.70 & 17.90 & 22.00 & 11.00 & 3.98 & 9.72 \\
\hline 3 & Fill & 5.00 & 17.80 & 24.00 & 11.60 & 4.55 & 11.11 \\
\hline 4 & Clay & 10.00 & 19.30 & 75.00 & 11.80 & 13.64 & 33.33 \\
\hline 5 & Sandstone & 20.00 & 24.00 & 140.00 & 30.00 & 1200.00 & 2000.00 \\
\hline
\end{tabular}

and hotel area. Through geotechnical investigation, the stratums of construction site are shown in Table 1.

There are two primary types of aquifers in the site. This first one is an unconfined aquifer, which is primarily the pore water in the third stratum. The water table depth is commonly 0.60 to $2.3 \mathrm{~m}$ below the ground. The second one is the confined aquifer. There is a weak confined aquifer in the fifth stratum, which is consisted of clay with large amount of lime concretions. Its water head is around 12.0 to $12.5 \mathrm{~m}$ below the ground, and it fluctuates between $0.5 \mathrm{~m}$ and $1.0 \mathrm{~m}$ annually. Another confined aquifer is deposited in the limestone bedrock. Its water head varies from $4.5 \mathrm{~m}$ to $7.8 \mathrm{~m}$ below the ground, and it fluctuates between $1.0 \mathrm{~m}$ and $4.0 \mathrm{~m}$ annually.

The original support system is chosen based on the deep excavation itself and its surrounding environment. Since the large-scale deep excavation studied in this paper is located in a complex geo-environment and high-density neighborhoods, the support system should be able to reduce the adverse effects of deep excavation to the minimum. The revolving digging cast-in-place grouting piles and pre-stressed anchors were constructed as the main support structures. The diameters of these piles are $1.0 \mathrm{~m}$ and the lengths of them vary from $18 \mathrm{~m}$ to $24 \mathrm{~m}$; and the piles were constructed at $1.2 \mathrm{~m}$ spacing. The section of top beam was $1.2 \mathrm{~m}$ long and $0.9 \mathrm{~m}$ wide. Meanwhile, deep mixing method were applied to create waterproof curtain, three-axis auger was used to create columns. The diameter of each column is $0.85 \mathrm{~m}$; and the columns were created at $1.2 \mathrm{~m}$ spacing. In the northwest corner of excavation, four layers reinforced concrete bracings were applied as temporary support. The structural section of excavation support is shown in Fig.2. Parameters of anchor cables and concrete bracings are shown in Table 2 and Table 3. The layout of monitoring points is shown in Fig.1. DB03-1, DB16-1, DB20-1, DB26-2 were settlement monitoring points, and the CX3, CX6 were piles lateral displacement monitoring points.

\section{Method}

The deep excavation was simplified as a cuboid which was $174 \mathrm{~m}$ long, $168 \mathrm{~m}$ wide, and $19.6 \mathrm{~m}$ deep, while the dimension of the whole model was $300 \mathrm{~m}$ long, $300 \mathrm{~m}$ wide, and $40 \mathrm{~m}$ deep. In this model, 310,000 elements and 326,432 nodes were generated. The visualized model of the deep excavation is shown in Fig.3.

In this $3 \mathrm{D}$ numerical model, mechanical behaviors of the soil elements were simulated by Mohr-Coulomb model; the excavation and the excavation support were simulated through the Null Elements and Structural Unit, respectively. According to the construction document, the elastic modulus of pre-stressed anchor cables is $195 \mathrm{GPa}$. For the retaining piles, top beam, and concrete bracings, the concrete grade is 30 , and their

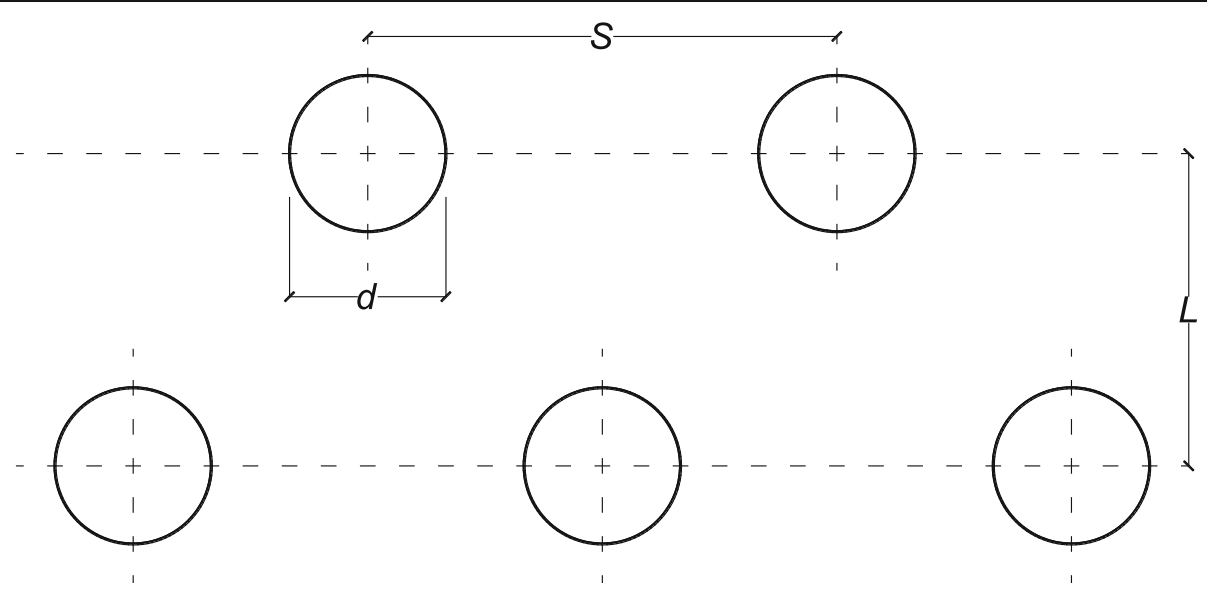

Fig. 4 Layout of quincunx double-row piles 
elastic modulus, Poisson's ratio and weight density are $30 \mathrm{GPa}, 0.20$ and $25 \mathrm{kN} / \mathrm{m}^{3}$, respectively. The model is divided into five layers corresponding to the natural stratums. The excavation does not reach the fifth layer. According to the geotechnical investigation of the construction site, the shear modulus $(\mathrm{G})$ and bulk modulus $(\mathrm{K})$ are obtained from Poisson's ratio $(v)$ and Young's modulus (E) by conversion formula (1) and (2). The soil parameter applied in model is shown in Table 4.

$$
\begin{aligned}
& G=\frac{E}{2(1+v)} \\
& K=\frac{E}{3(1-2 v)}
\end{aligned}
$$

There are six primary construction steps for the excavation: (1) lowered the ground water table to $-22.6 \mathrm{~m}$ (22.6 $\mathrm{m}$ below the ground), and constructed retaining piles, stud piles, and waterproof curtain; (2) excavate the first layer of soil to $-4.3 \mathrm{~m}$, and constructed the top beam, the first bracing and anchor cables; (3) excavate the second layer of soil to $-8.3 \mathrm{~m}$, and constructed the second bracing and anchor cables; (4) excavate the third layer of soil to $-12.3 \mathrm{~m}$, and constructed the third bracing and anchor cables; (5) excavate the fourth layer of soil to $-16.3 \mathrm{~m}$, and constructed the fourth bracing and anchor cables; (6) excavate to $-16.3 \mathrm{~m}$, which is the bottom of the deep excavation.

Besides the original excavation support applied in the construction site, a different support system that replaced the piles-anchor with quincunx double-row piles is proposed and simulated in the model. The material parameters are the same as the ones in original support system. The layout of quincunx double-row piles is shown in Fig.4. Three independent factors: pile diameter $(d)$, pile space $(S)$, and row space $(L)$ on supporting effect were considered in models. And as shown in Table 5, three levels were set for each factor.

\section{Results and discussion}

The lateral displacement of retaining piles and the settlement around the excavation can be considered as straightforward and effective indicators, which can

Table 5 Factor level charts

\begin{tabular}{llll}
\hline Levels & $\begin{array}{l}\text { (A) Pile Diameter } \\
(\text { d } / \mathrm{mm}\end{array}$ & $\begin{array}{l}\text { (B) Pile Space } \\
\text { (S)/mm }\end{array}$ & $\begin{array}{l}\text { (C) Row Space } \\
(\mathrm{L}) / \mathrm{mm}\end{array}$ \\
\hline 1 & 600 & 1200 & 1200 \\
2 & 800 & 2400 & 1800 \\
3 & 1000 & 3600 & 2400 \\
\hline
\end{tabular}

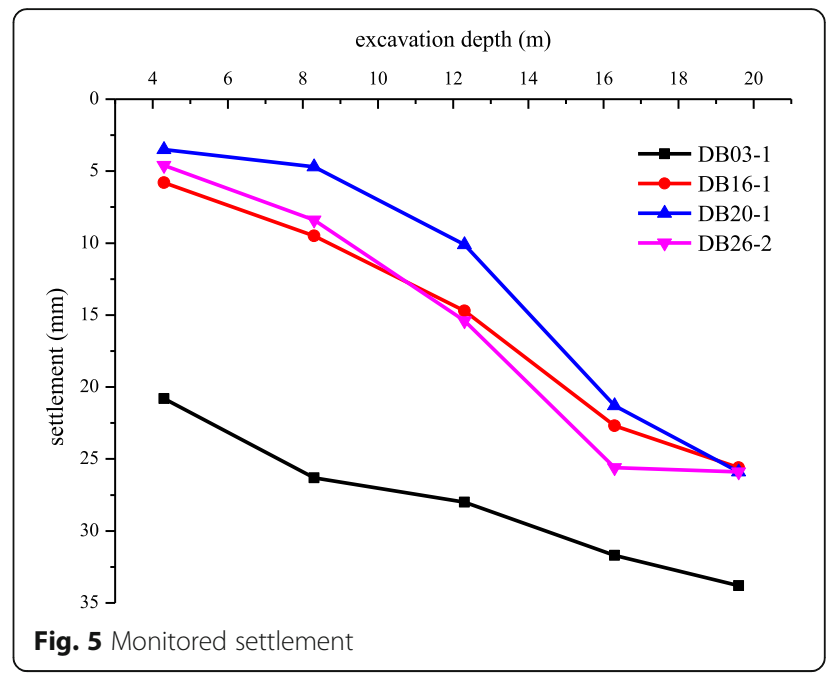

reflect the safety of excavation. They can also be used to evaluate the adverse effect brought by excavation on the surrounding environment. Therefore, these two indicators were applied to study the performance of different excavation support systems.

\section{Pile-anchor support system}

The settlement of each monitoring point (DB03-1, DB16-1, DB20-1 and DB26-2) changed with the increase of excavation depth (shown in Fig.5). It can be seen that the maximum settlement around the excavation were $33.80 \mathrm{~mm}, 25.60 \mathrm{~mm}, 25.90 \mathrm{~mm}$ and $25.90 \mathrm{~mm}$, respectively, which were all less than the alarming settlement $35 \mathrm{~mm}$. It indicated that the deep excavation was safe during the whole construction. In Fig. 5, it can be seen that the settlement of DB03-1 was distinctly larger than the other spots. It is because that the stress of soil and retaining structures was disturbed by the construction of municipal engineering nearby the settlement monitoring point

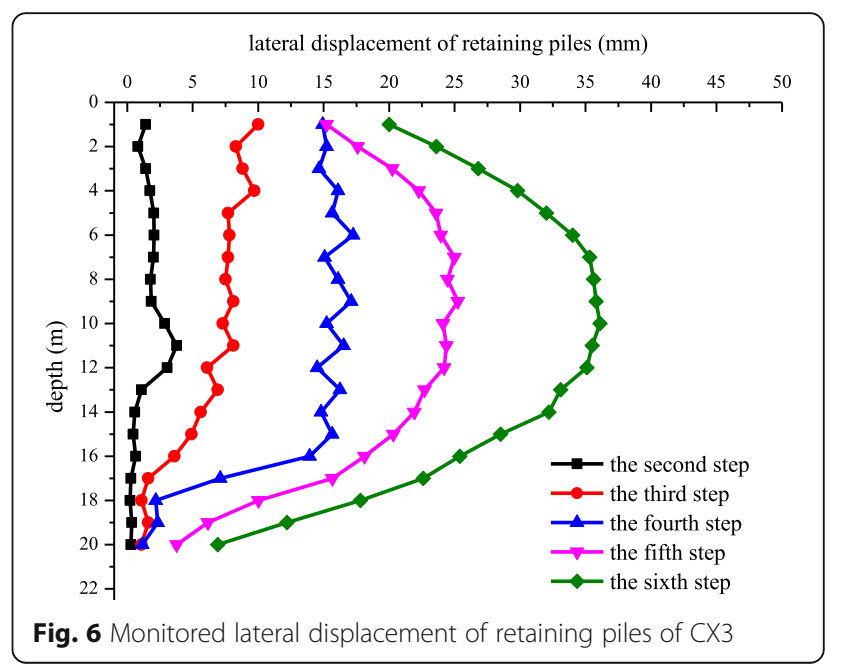




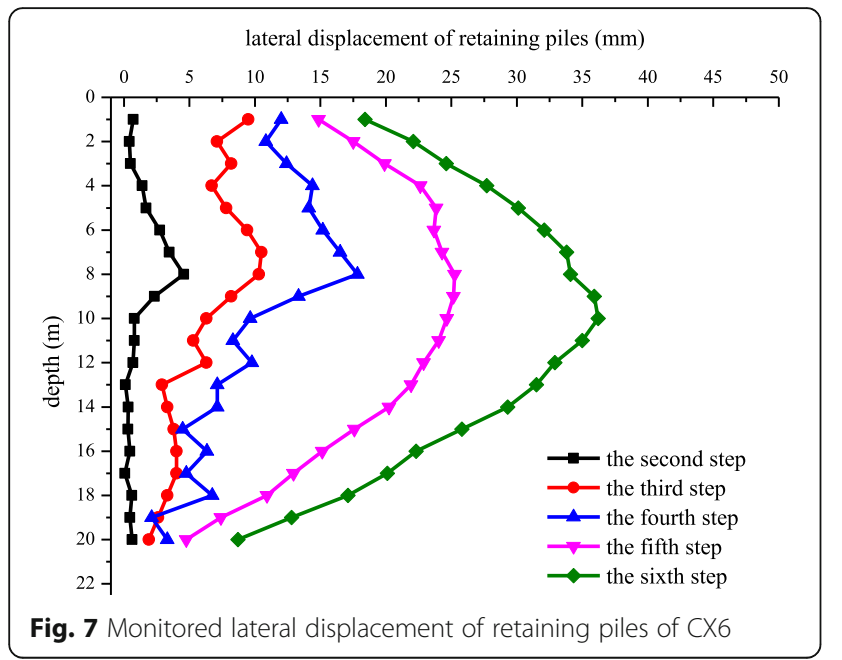

DB03-1 at the second step, which increase the settlement of DB03-1.

The changes of lateral displacement of retaining piles that monitored by $\mathrm{CX} 3$ and CX6 during excavation are shown in Fig.6 and Fig.7. It can be seen that the maximum lateral displacements of retaining piles are $36.00 \mathrm{~mm}$ and $36.20 \mathrm{~mm}$ respectively, which are both less than the alarm value of $50.00 \mathrm{~mm}$. In the initial stage of excavation, the lateral displacement of retaining piles is small. The lateral displacement in the upper and middle section of retaining piles increase with excavation, while the lateral displacement in the upper section is restricted after the installment of anchors cables. The excavation lasted for a long time because of various reasons, such as rainfall, residue soil embargo and the security check. Therefore, the lateral displacement of retaining piles increased significantly with the increase of exposure time, which is known as time-space effect.

Dewatering has been completed before excavation. Therefore, in this paper, the settlement caused by dewatering was inverted. Simulated settlement of each settlement monitoring point at completion time for the first step and the percentage of simulated total settlement is shown in Table 6.

It can be seen in Table 6 that the settlement caused by dewatering before excavation are $2.74 \mathrm{~mm}, 2.74 \mathrm{~mm}$, $2.74 \mathrm{~mm}$ and $1.90 \mathrm{~mm}$ respectively, and the percentage of total settlement are $15.56 \%, 15.62 \%, 17.03 \%$ and $10.88 \%$ respectively. The settlement at the first step was

Table $\mathbf{6}$ Simulated settlement at the first step and the percentage of simulated total settlement

\begin{tabular}{lllll}
\hline Monitoring point & DB03-1 & DB16-1 & DB20-1 & DB26-2 \\
\hline Settlement $(\mathrm{mm})$ & 2.74 & 2.74 & 2.74 & 1.90 \\
$\begin{array}{l}\text { Percentage of Simulated } \\
\text { Total Settlement (\%) }\end{array}$ & 15.56 & 15.62 & 17.03 & 10.88 \\
\hline
\end{tabular}

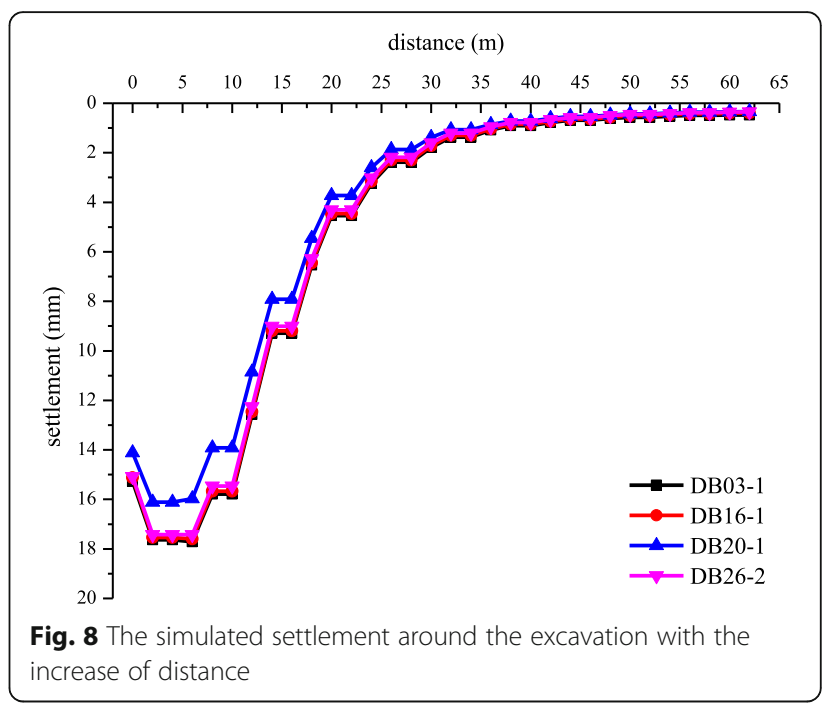

caused by consolidation, and the influence of dewatering cannot be ignored.

Simulated settlement around the excavation versus distance of monitoring points DB03-1, DB16-1, DB20-1 and DB26-2 is shown in Fig.8. It can be seen that there is a great settlement nearby the excavation because of the construction of retaining piles and waterproof curtain. With the increase of distance, the simulated settlement decreases: when the distance is greater than $6 \mathrm{~m}$, the simulated settlement decreases rapidly due to the support of retaining piles; when the distance is greater than $26 \mathrm{~m}$, the simulated settlement decreases slowly; when the distance increases to $38 \mathrm{~m}$, the simulated settlements are all less than $1.00 \mathrm{~mm}$. The Xuzhou department store located in the northwest of excavation is $12.10 \mathrm{~m}$ far away from excavation edge. In that site, the simulated settlement is $10.34 \mathrm{~mm}$, and it continues to decrease with the increase of distance. The normal use of Xuzhou department store is not affected by excavation.

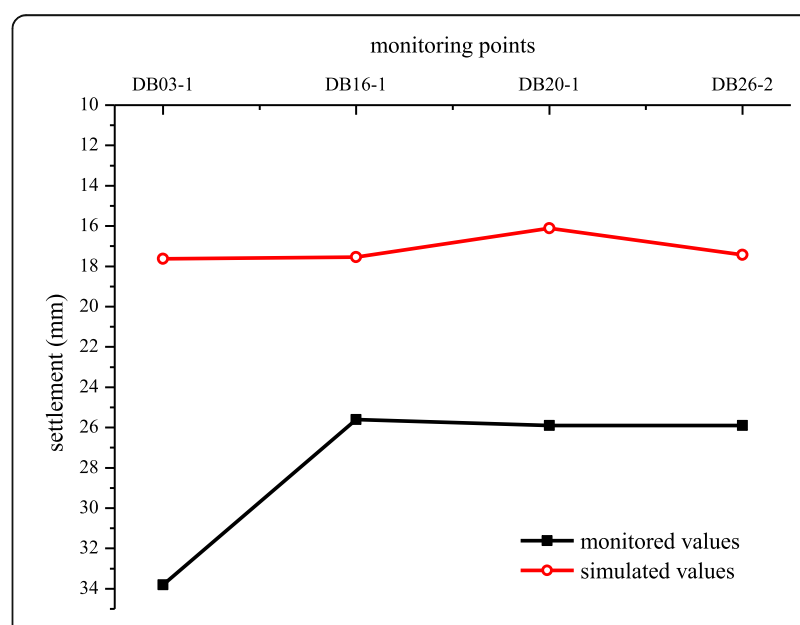

Fig. 9 Monitored and simulated settlements 
Monitored and simulated settlement of each settlement monitoring point at completion time for sixth step is shown in Fig.9. It can be seen in Fig.9 that the monitored settlement is greater than simulated settlement in each settlement monitoring point, while the monitored values and the simulated values are in the same order of magnitude. Due to the construction of municipal engineering in the south of excavation was not considered in numerical simulation, deviation of monitored and simulated settlement of monitoring point DB03-1 is greater than others.

The shape of the excavation and the arrangement of retaining structures are approximately symmetrical, hence the lateral displacement of retaining piles in $\mathrm{x}$ direction and y direction are approximately equal, and the latter is analyzed as an example. The monitored and simulated lateral displacements of retaining piles of monitoring point CX6 are shown in Fig.10, and it can be seen that those are close and the deformation trend is basically identical. The deviation of monitored and simulated lateral displacement of retaining piles is caused by the simplification of deep excavation. The third stratum, which has large thickness, is consisted by soils with poor engineering properties. The lateral displacement of retaining piles increase significantly during excavation at this depth, and the deformation along the depth demonstrate as an arch.

\section{Quincunx double-row piles support system}

The simulated settlement of point DB20-1 and simulated the maximum lateral displacements of point CX6 are selected as evaluation indexes. Based on the levels in the orthogonal table, nine groups of simulation tests were carried out. The test results and the analysis are shown in Table 7, Table 8 and Fig.11. In Table $8, K_{i}$ represents the summation of the corresponding test
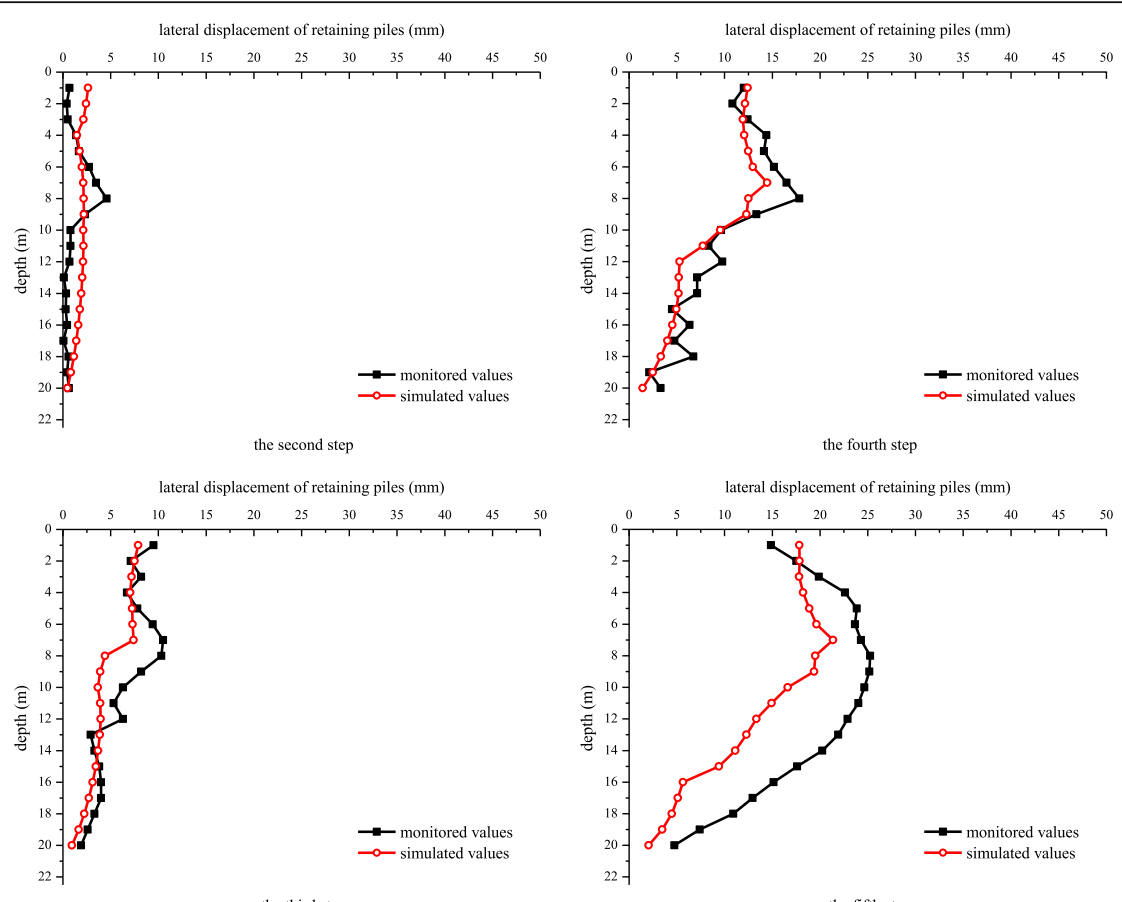

he third step

the fifth step

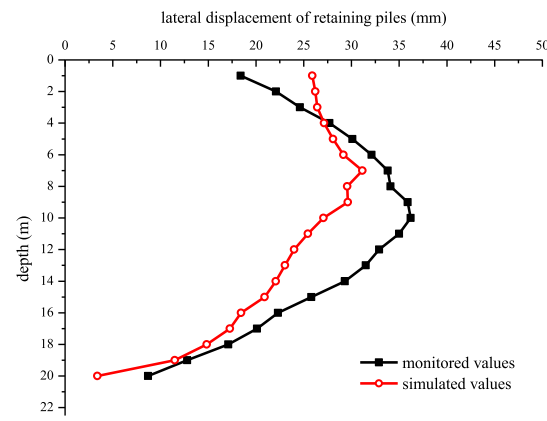

the sixth step

Fig. 10 Monitored and simulated lateral displacements of point CX6 
Table 7 Results of test

\begin{tabular}{lllllll}
\hline Test number & A & B & Blank column & C & Settlement/mm & The maximum lateral displacement of piles/mm \\
\hline 1 & 1 & 1 & 1 & 1 & 11.53 & 27.08 \\
2 & 1 & 2 & 2 & 2 & 13.62 & 29.35 \\
3 & 1 & 3 & 3 & 3 & 14.92 & 30.68 \\
4 & 2 & 1 & 2 & 3 & 12.32 & 27.69 \\
5 & 2 & 2 & 3 & 1 & 14.54 & 30.15 \\
6 & 2 & 3 & 1 & 2 & 15.30 & 31.05 \\
7 & 3 & 1 & 3 & 2 & 14.04 & 29.32 \\
8 & 3 & 2 & 1 & 3 & 15.27 & 30.71 \\
9 & 3 & 3 & 2 & 1 & 16.21 & 31.88 \\
\hline
\end{tabular}

results of level $i$ on any column; $k_{i}$ represents the arithmetic average of test results of level $i$ on any column; $R$ represents the range, and $R=\max \left\{K_{1}, K_{2}, K_{3}\right\}$ $-\min \left\{K_{1}, K_{2}, K_{3}\right\}$ or $R=\max \left\{k_{1}, k_{2}, k_{3}\right\}-\min \left\{k_{1}, k_{2}\right.$, $k_{3}$ \} (Xu et al. 2002).

In Table 8, it can be seen that for the both index, it has $R_{\mathrm{B}}>R_{\mathrm{A}}>R_{\mathrm{C}}$, which indicates that the factor $\mathrm{B}$ has greater influence on test results than $A$, and $A$ is greater than $\mathrm{C}$. The factors can be ranged as follows: pile space, pile diameter, row space. The optimal solutions for two evaluation indexes are determined by the minimum $K_{i}$ for each factor, and they are $\mathrm{B}_{1} \mathrm{~A}_{1} \mathrm{C}_{1}$ and $\mathrm{B}_{1} \mathrm{~A}_{1} \mathrm{C}_{3}$ respectively. When the row space corresponds to $2400 \mathrm{~mm}$, a small lateral displacement of retaining piles is obtained, and it is beneficial to the security of excavation. Hence, $\mathrm{B}_{1} \mathrm{~A}_{1} \mathrm{C}_{3}$ is selected as the optimum solution, and the pile diameter, pile space, row space correspond to $600 \mathrm{~mm}, 1200 \mathrm{~mm}, 2400 \mathrm{~mm}$ respectively.

In Fig.11, it can be seen that with the increase of row space from $1200 \mathrm{~mm}$ to $2400 \mathrm{~mm}$, the settlement and the maximum lateral displacement of retaining piles slowly increase at first then decrease slightly, and the variation is very small. It is indicated that the row space of quincunx double-row piles has a little influence on the settlement around the excavation and the lateral displacement of retaining piles than pile diameter and pile space. With the increase of pile space from $1200 \mathrm{~mm}$ to $3600 \mathrm{~mm}$, the settlement and the maximum lateral displacement of retaining piles increase, and the change of pile space has a very obvious influence on the lateral displacement of retaining piles.

Table 8 Analysis of test results

\begin{tabular}{|c|c|c|c|c|c|}
\hline \multirow{2}{*}{$\begin{array}{l}\text { Evaluation index } \\
\text { Settlement/mm }\end{array}$} & \multirow[b]{2}{*}{$K_{1}$} & \multirow{2}{*}{$\begin{array}{l}\text { A } \\
40.07\end{array}$} & \multicolumn{2}{|l|}{ B } & \multirow{2}{*}{$\frac{C}{42.28}$} \\
\hline & & & 37.89 & 42.10 & \\
\hline & $K_{2}$ & 42.16 & 43.43 & 42.15 & 42.96 \\
\hline & $K_{3}$ & 45.52 & 46.43 & 43.50 & 42.51 \\
\hline & $k_{1}$ & 13.36 & 12.63 & 14.03 & 14.09 \\
\hline & $k_{2}$ & 14.05 & 14.48 & 14.05 & 14.32 \\
\hline & $k_{3}$ & 15.17 & 15.48 & 14.50 & 14.17 \\
\hline & $R$ & 5.45 & 8.54 & 1.40 & 0.68 \\
\hline & Influence Degree & B A C & & & \\
\hline & Optimal Solution & $\mathrm{B}_{1} \mathrm{~A}_{1} \mathrm{C}_{1}$ & & & \\
\hline \multirow[t]{9}{*}{ The Maximum Lateral Displacement of Retaining Piles/mm } & $K_{1}$ & 87.11 & 84.09 & 88.84 & 89.11 \\
\hline & $K_{2}$ & 88.89 & 90.21 & 88.92 & 89.72 \\
\hline & $K_{3}$ & 91.91 & 93.61 & 90.15 & 89.08 \\
\hline & $k_{1}$ & 29.04 & 28.03 & 29.61 & 29.70 \\
\hline & $k_{2}$ & 29.63 & 30.07 & 29.64 & 29.91 \\
\hline & $k_{3}$ & 30.64 & 31.20 & 30.05 & 29.69 \\
\hline & $R$ & 4.80 & 9.52 & 1.31 & 0.64 \\
\hline & Influence Degree & B A C & & & \\
\hline & Optimal Solution & $\mathrm{B}_{1} \mathrm{~A}_{1} \mathrm{C}_{3}$ & & & \\
\hline
\end{tabular}



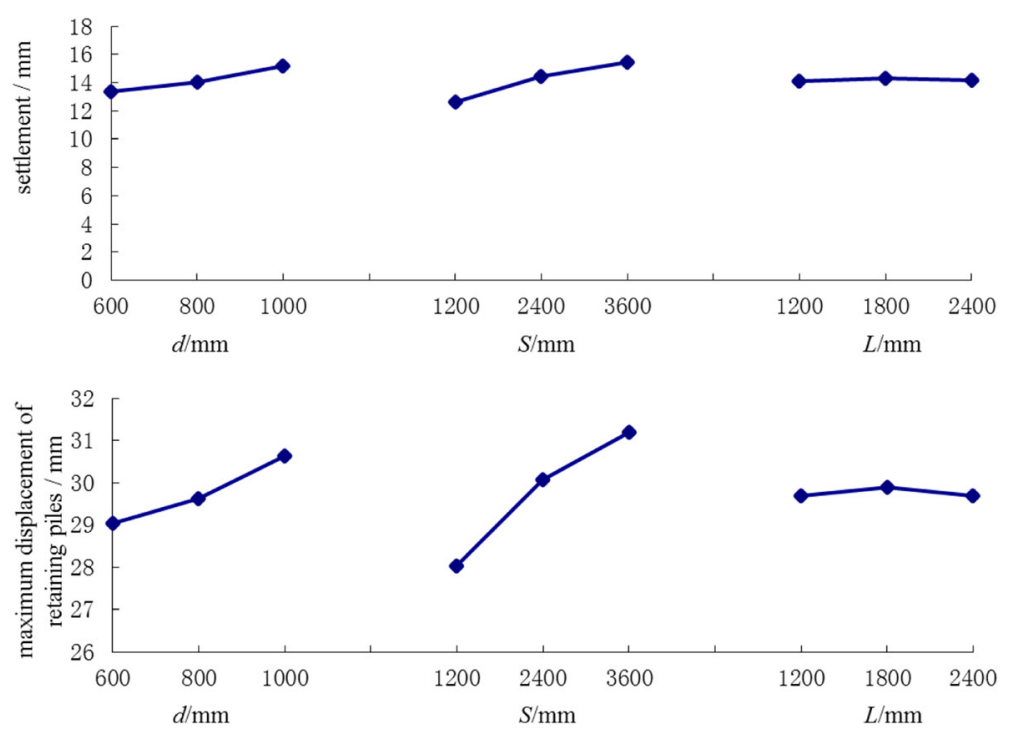

Fig. 11 Trend graph

The comparisons of pile-anchor support system with optimum solution are shown in Fig.12 and Fig.13. It can be seen from Fig.12 and Fig.13 that the simulated settlement around the excavation and the lateral displacement of retaining piles of the pile-anchor support system and optimum solution are close, and the trends of deformation are identical. The simulated settlement around the excavation and the lateral displacement of retaining piles of optimum solution are both smaller than pile-anchor support system. The simulated settlement around the excavation in optimum solution is about 0.70 0.72 times the settlement in pile-anchor support system; the lateral displacement of retaining piles in the upper and middle section of the pile in optimum solution is about $0.83 \sim 0.90$ times the displacement in pile-anchor support system. There is little difference in the bottom section of the pile. It is indicated that the

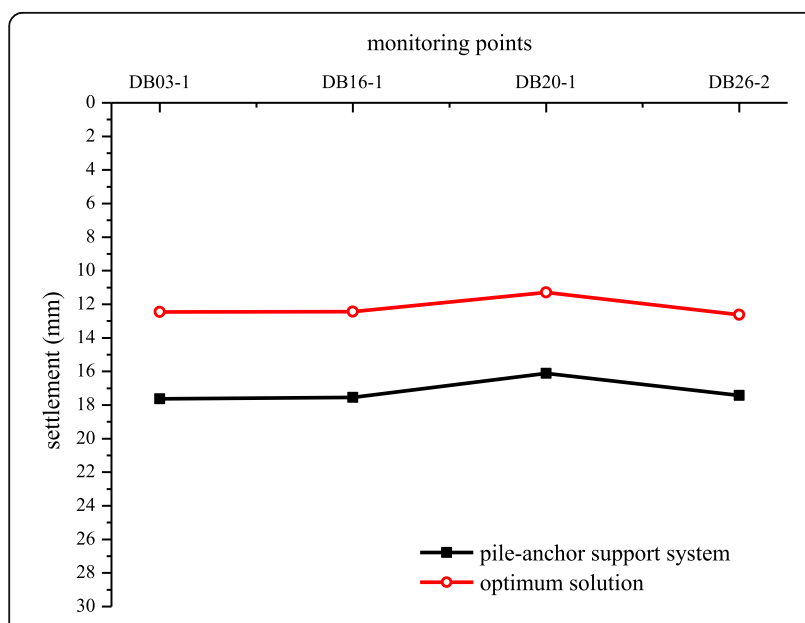

Fig. 12 Simulated settlement of two support Systems quincunx double-row piles support system with reasonable parameters can effectively restrict the settlement around the excavation and the lateral displacement of retaining piles, therefore, can optimize the supporting effect.

\section{Conclusions}

The simulated settlement around the excavation caused by dewatering is great, as well as the percentage of simulated total settlement. Hence the influence of dewatering cannot be ignored.

Through the analysis of monitored lateral displacement of retaining piles and numerical simulation results, it is cleared that the lateral displacement of retaining piles is prone to be large at a depth, where the stratum has large thickness and is consisted by soils with poor engineering properties during excavation.

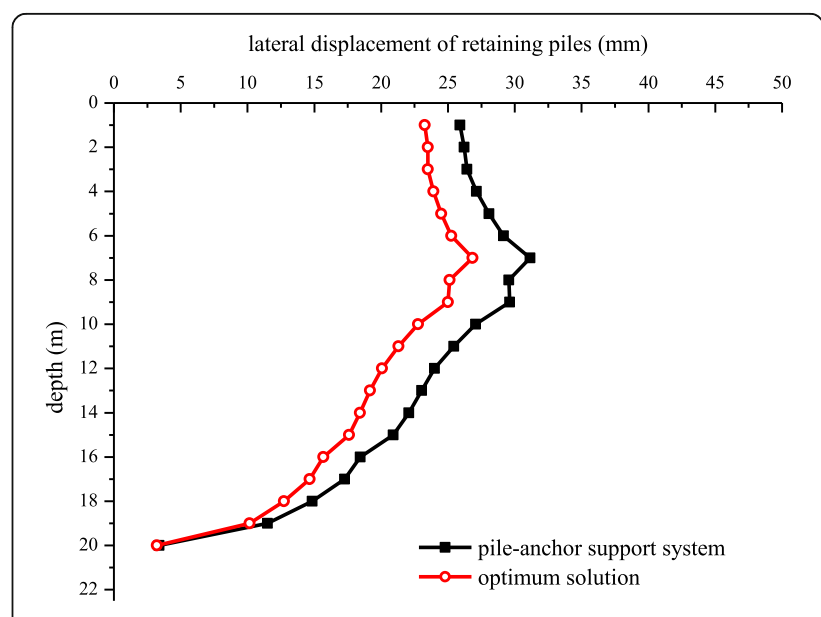

Fig. 13 Simulated lateral displacement of two support systems 
In quincunx double-row piles support system, pile space is the primary factor affecting the settlement around the excavation and the lateral displacement of retaining piles, especially for the latter. Row space has little effect on the settlement around the excavation and lateral displacement of retaining piles.

For the construction of deep excavation in similar geoenvironments, the quincunx double-row piles support system with reasonable parameters can effectively restrict the settlement around the excavation and the lateral displacement of retaining piles, therefore, can optimize the supporting effect.

Authors' contributions

YT, WZ and JZ participated in the discussion the results of the survey. WZ

drafted the manuscript. All authors read and approved the final manuscript.

\section{Competing interests}

The authors declare that they have no competing interests.

\section{Publisher's Note}

Springer Nature remains neutral with regard to jurisdictional claims in published maps and institutional affiliations.

Received: 19 May 2017 Accepted: 3 October 2017

Published online: 18 October 2017

\section{References}

Finno, R.J., S.A. Lawrence, N.F. Allawh, and I.S. Harahap. 1991. Analysis of performance of pile groups adjacent to deep excavation. Journal of Geotechnical Engineering 117 (6): 934-955.

Gao, G.Y., M. Gao, C.B. Yang, and Z.S. Yu. 2010. Influence of deep excavation on deformation of operating metro tunnels and countermeasures. Chinese Journal of Geotechnical Engineering 32 (3): 453-459.

Goh, A.T.C., K.S. Wong, C.I. Teh, and D. Wen. 2003. Pile response adjacent to braced excavation. Journal of Geotechnical and Geoenvironmental Engineering 129 (4): 383-386.

Ou, C.Y., P.G. Hsieh, and D.C. Chiou. 1993. Characteristics of ground surface settlement during excavation. Canadian Geotechnical Journal 30 (5): 758-767.

Peck, R.B. 1969. Deep excavations and tunnelling in soft ground. In Proc. 7th int. conf. On SMFE, 225-290.

Poulos, H.G., and L.T. Chen. 1997. Pile response due to excavation-induced lateral soil movement. Journal of Geotechnical and Geoenvironmental Engineering 123 (2): 94-99.

Xu, Z.A., T. Wang, and C. Li. 2002. Brief introduction to the orthogonal test design SCl. Tech Information Development \& Economy 12: 148-150.

Zhang, R., J. Zheng, H. Pu, and L. Zhang. 2011. Analysis of excavation-induced responses of loaded pile foundations considering unloading effect. Tunnelling and Underground Space Technology 26 (2): 320-335.

Zhou, N.Q., Y.Q. Tang, R.X. Lou, and S.M. Jiang. 2011. Numerical simulation of deep foundation pit dewatering and land subsidence control of Xujiahui Metro Station. Chinese Journal of Geotechnical Engineering 33 (12): 1951-1956.

\section{Submit your manuscript to a SpringerOpen ${ }^{\circ}$ journal and benefit from:}

- Convenient online submission

- Rigorous peer review

- Open access: articles freely available online

- High visibility within the field

- Retaining the copyright to your article 